\title{
Izabela Lewandowska
}

\section{Warmia i Mazury jako palimpsest, czyli o oswajaniu poniemieckiej przestrzeni po drugiej wojnie światowej}

Palimpsest to przenośnia adekwatna zarówno do przestrzeni, tj. Warmii i Mazur, jak i do okresu - po drugiej wojnie światowej. Wtedy nastąpiło ponowne ,zapisywanie” tego terytorium nowymi znakami, symbolami, nazwami, nową architekturą, pozbawioną elementów pruskich, nowymi tradycjami odwołującymi się wyłącznie do polskich fragmentów historii. Po ucieczce, a następnie wysiedleniu Niemców, nowi osadnicy próbowali oswoić obce im kulturowo przestrzenie: zajmowali ewangelickie świątynie, przeznaczając je na miejsca kultu katolickiego, burzyli niemieckie pomniki, zmieniali drogowskazy z niemieckimi nazwami, szykanowali mówiących po niemiecku Warmiaków i Mazurów. W artykule zostanie poruszona kwestia zniszczeń wojennych, rządowych nakazów likwidacji pozostałości niemieckich, sporów o układ architektoniczny miast, adaptowania zabytków na budynki dostosowane do potrzeb społecznych, oswajania zabytków kościelnych, zagospodarowywania poniemieckich pałaców i dworów.

Słowa kluczowe: Warmia, Mazury, architektura, przestrzeń kulturowa, zmiany krajobrazu.

Conservatio est aeterna creatio.

Zachowanie dawnych form architektury jest twórczą działalnością człowieka skierowaną ku przyszłym pokoleniom (Muszyński 1997, s. 246).

\section{Wstęp}

Po drugiej wojnie światowej na Warmii i Mazurach można zauważyć ambiwalencję postaw społecznych. Uciekający lub wysiedlani Niemcy pozostawiali dorobek swojego życia i wieloletnich rządów w postaci obiektów architektonicznych, śladów w przestrzeni (np. nazewnictwa czy pomników) oraz zabytków ruchomych. Polscy osadnicy próbowali oswoić tę przestrzeń, burząc to, co zastali, i nadając jej nowe znaczenie kulturowe. Jednocześnie wiele uwagi, a także pieniędzy poświęcono na odbudowę krzyżackich i biskupich zamków (w Kętrzynie, Nidzicy, Lidzbarku Warmińskim, Reszlu). W ten sposób spod symboliki pruskiej i polskiej zaczęły prześwitywać wcześniej zapisane karty dziejów. Okazało się, że 
dziedzictwo kulturowe Warmii i Mazur jest spuścizną wielu nacji i etnosów - staropruskiego, krzyżackiego, polskiego, niemieckiego, rosyjskiego, holenderskiego i innych. Dzisiaj na tej podstawie staramy się nauczać młodzież i zmieniać świadomość dorosłych, choć nie jest to łatwe zadanie.

Przystosowanie po drugiej wojnie światowej architektury na Ziemiach Odzyskanych ${ }^{1}$ do polskich wyobrażeń i oczekiwań było zadaniem bardzo trudnym. $\mathrm{Z}$ jednej strony, w myśl założeń ideologicznych, należało oczyścić ją z naleciałości germańskich, $\mathrm{z}$ drugiej - zachować to, co cenne z punktu widzenia zabytkowego (Jasiński 2006). Poza tym do głosu dochodziły roszczenia architektów i urbanistów, którzy widzieli potrzebę rozluźnienia ciasnej zabudowy i przeprowadzenia nowych, szerokich ciągów komunikacyjnych, niszczących stare, zabytkowe układy przestrzenne. Na to nakładały się problemy związane z odgruzowywaniem i porządkowaniem miast, które w znacznej mierze leżały w ruinie.

Artykuł powstał głównie na podstawie opracowań naukowych i literatury z okresu bezpośrednio powojennego, stanowiące źródło, które można wykorzystać do oceny ówczesnej świadomości historycznej. Tekst jest pokłosiem szerszych badań prowadzonych nad stosunkiem władz polskich i mieszkańców regionu do zastanego na Warmii i Mazurach dziedzictwa kulturowego (Lewandowska 2012). Palimpsest, oznaczający dokładnie nadpisanie nowego tekstu w miejscu starego, w tym wypadku należy rozumieć jako zmiany krajobrazu kulturowego, przestrzeni i architektury, które usuwają poprzedni wygląd i wyobrażenie, a dają zupełnie inny obraz rzeczywistości. Należy tu zadać pytanie o realne możliwości zachowania autentycznej, zabytkowej architektury miast (Liżewska 2000). Jak w ówczesnej sytuacji można było myśleć o tym, czy wygląd danej kamienicy, zamku lub kościoła ma rodowód polski? Kto powinien decydować o odbudowie w takim, a nie innym stylu? Kto miał finansować ewentualne przebudowy, zważywszy, że brakowało pieniędzy na podstawowe potrzeby - mieszkania, drogi, środki transportu, żywność? To zagadnienie łączy się z wieloma wątkami i problemami, które poddawane są analizie naukowej.

\section{Oswajanie krajobrazu}

Przez stulecia krajobraz kulturowy ziem pruskich kształtowany był przez osadnictwo niemieckie, polskie, litewskie, holenderskie, salzburskie i rosyjskie (filipońskie). Na krajobraz naturalny nałożyła się działalność człowieka, który przynosił

${ }^{1}$ W latach 1945-1949 była to oficjalnie obowiązująca nazwa tych ziem. W odniesieniu do lat późniejszych autorka używa terminu Ziemie Zachodnie i Północne. 
ze swej macierzystej ziemi własną kulturę rolną, sposób zagospodarowania przestrzeni, charakterystyczne uprawy itp. W krajobraz, poprzez specyficzną symbolikę, wpisywały się elementy kultury duchowej - krzyże, kapliczki, pomniki. Układy przestrzenne wsi i miast, powstałe $\mathrm{w}$ wyniku lokacji i w procesie zasiedlania, nie zmieniały się przez wieki. Dopiero w XIX w., przynoszącym przemiany uwłaszczeniowe, separację i meliorację gruntów, zaszły znaczne zmiany w przestrzennym rozłożeniu wsi i okalających je pól (Jasiński 2002). Substancja zabytkowa, głównie drewniana, także ulegała zniszczeniom spowodowanym wojnami, przemarszami wojsk oraz licznymi pożarami.

Mimo to ludność, wrośnięta od pokoleń w tę ziemię, przyzwyczajała się do zastanego, a zarazem osobiście kształtowanego krajobrazu. Emocjonalny stosunek człowieka do miejsca, w którym żyje, daje mu poczucie swojskości - świadomość bycia u siebie. Życie wśród ludzi odnoszących się w ten sam sposób do wspólnego miejsca i kultywujących tę samą tradycję daje natomiast inny wymiar swojskości - świadomość bycia wśród swoich (Pawłowska 1996). Takie podejście do zajmowanej przestrzeni stwarza szansę na rozwój, a ludziom daje poczucie bezpieczeństwa.

Przesiedlenie, deportacja, czy też nawet tylko zwykła przeprowadzka prowadzą do wyobcowania i kryzysów tożsamości. Dopiero gdy przestrzeń bez właściwości zostanie wypełniona nowymi symbolami, może stać się nową ojczyzną, miejscem łatwego działania (Lukowski 2002, s. 91).

Oswojona przestrzeń daje poczucie stabilizacji, pewności i orientacji. Dopiero wtedy można mówić o procesie zakorzeniania się, będącego jednym z przestrzennych aspektów tożsamości.

$\mathrm{Na}$ Warmię i Mazury, szczególnie w okolice wiejskie, kierowano po wojnie przesiedleńców z Wileńszczyzny i Grodzieńszczyzny, krajobraz i klimat tych regionów był bowiem bardzo podobny. Oni przywozili ze sobą święte obrazy i wyposażenie wnętrz, a zastane tu kapliczki i przydrożne krzyże były im bliskie, podobnie jak ludności rodzimej - Warmiakom i Mazurom. Po drugiej wojnie światowej przestrzeń wiejska regionu niewiele się zmieniła. Nawet utworzenie Państwowych Gospodarstw Rolnych i umiejscowienie ich w dawnych folwarkach junkrów pruskich niezbyt wpłynęło na wygląd samej wsi. Przeobrażenia rozpoczęły się w latach późniejszych (60. i 70. XX w.) i były związane z odejściem od tradycyjnej uprawy roli na rzecz „nowoczesności”. W środku wsi budowano bloki mieszkalne, sklepy, ośrodek zdrowia, świetlicę. Coraz rzadziej korzystano z karczmy czy młyna, które nieużywane i nieremontowane, popadały w ruinę. Wtedy można je było rozebrać bez żadnych konsekwencji. Młodzież uciekała ze wsi do 
miast i zrywała więzi z tradycją swojej rodziny i środowiska lokalnego. Wiele zabytków ruchomych, uznanych za staroświeckie, chowano na strychach i w chlewikach, a nawet palono nimi w piecach.

\section{Przemiany architektury miast}

Inaczej niż w przestrzeni wiejskiej dokonywały się przemiany w wyglądzie miast. W wyniku działań wojennych, a następnie celowych podpaleń dokonywanych przez Armię Czerwoną unicestwiono cenne zabytkowe zespoły staromiejskie Elbląga (98\%), Pieniężna (95\%), Fromborka (90\%), Braniewa (85\%), Iławy $(80 \%)$ i wielu innych. Dwadzieścia miejscowości utraciło prawa miejskie (m.in. Dąbrówno, Kisielce, Miłakowo, Miłomłyn, Młynary, Zalewo).

$Z$ dużym prawdopodobieństwem można przyjąć, że na omawianym obszarze zniszczono co najmniej 16000 zabytkowych kamienic, nie mniej niż 55 obiektów sakralnych oraz około 14 zamków i założeń pałacowych, nie licząc takich zespołów, jak: Wzgórze Katedralne we Fromborku, elbląskie Stare Miasto czy zespół zamkowy w Malborku (Domagała 1998, s. 42).

Miasta należało najpierw uprzątnąć z gruzu, którego w 1953 r. zalegało jeszcze $3 \mathrm{mln} \mathrm{m}^{3}$. W pierwszych latach powojennych podejmowano kilka akcji odgruzowywania. Były one $\mathrm{z}$ jednej strony niezbędne do normalnego funkcjonowania, z drugiej zaś przyczyniły się do zniszczenia wielu detali architektonicznych czy rozebrania resztek kamienic i murów obronnych, które można było odbudować. W ten sposób zniszczono zabytkowe układy przestrzenne małych miast, które pozbawiono XIX-wiecznej zabudowy. Dla przykładu w 1954 r. rozebrano fragmenty obwarowań w Lidzbarku Warmińskim i Kętrzynie, a w 1955 r. - w Morągu i Dobrym Mieście. Oceniając to postępowanie, warto pamiętać, że wśród konserwatorów panowało wówczas przekonanie o znaczeniu granicznej daty $1850 \mathrm{r}$. w uznaniu obiektu za zabytek. Aż do lat 60. XX w. nie dostrzegano wartości zabytkowej w przykładach architektury późniejszej niż połowa XIX w. Konsekwencje takiej postawy to rezygnacja $\mathrm{z}$ odtwarzania pochodzących $\mathrm{z}$ tamtych lat budynków i elementów wystroju oraz wyburzanie budynków uszkodzonych. W związku $\mathrm{z}$ takim podejściem usprawiedliwione były akcje odgruzowywania, zwane też akcjami odzyskowymi, które miały służyć pozyskaniu materiałów budowlanych, głównie cegieł i dachówek, na odbudowę Warszawy, Gdańska czy Wrocławia.

Była to sytuacja sprzyjająca wprowadzeniu nowego zagospodarowania terenów miejskich, związana ze zmianami ideologicznymi. Po drugiej wojnie światowej ziemie przyznane Polsce na zachodzie i północy kraju były nasycone 
elementami kultury niemieckiej i dlatego polscy osadnicy uznawali te tereny za obce. $Z$ tego powodu władzom zależało na szybkim i kategorycznym zerwaniu wszelkich więzi tego terenu z niemiecką przeszłością.

Zdawali sobie z tego sprawę polscy Mazurzy, którzy już w 1944 r. przygotowali Memoriat w sprawie Prus Wschodnich dla nowych władz polskich. W rozdziale VII, zatytułowanym Zabytki, pisano:

28. Polskie. Specjalną opieką otoczyć trzeba od razu z chwilą włączenia Mazur do Polski wszelkie zabytki rodzimej sztuki polskiej i pamiątki polskiej pracy twórczej oraz pomniki walki narodowej ludu polskiego z niemieckim najeźdźcą. Nie można zezwolić np. na zniszczenie „Kamienia Jagiełly” pod Stembarkiem - pomimo jego napisu niemieckiego o śmierci wielkiego mistrza krzyżackiego Ulricha von Jungingen. Należałoby tylko zmienić napis niemiecki na polski z dodaniem zwrotu: „zginął ukarany za zbrodnie, dokonane przez krzyżactwo na narodzie polskim". Pomnik Kopernika w Olsztynie musi ze zmianą napisu niemieckiego na polski zachowany zostać nadal (ryc. 1). 29. Niemieckie. Wszystkie zabytki, pomniki i pamiątki panowania Niemców na terenie ziemi mazurskiej usunie się radykalnie i bezapelacyjnie. Nie wolno ich pozostawić nawet mimo ich wartości artystycznych, architektonicznych, czy też naukowych. Muszą zniknąc bezpowrotnie. Zniknąć musi „Dąb Bismarka" [w lasach napiwodzkich, k. Nidzicy - przyp. I.L.] i mauzoleum Hindenburga [k. Olsztynka - przyp. I.L.]. Zniknąć musi każdy zamek krzyżacki, stojący na kościach robotnika polskiego i wiele innych. Ziemia mazurska i jej mieszkaniec - Mazur - musi natychmiast przyjąć czyste oblicze mazurskie - polskie (Filipkowski 1980, s. 77-78).

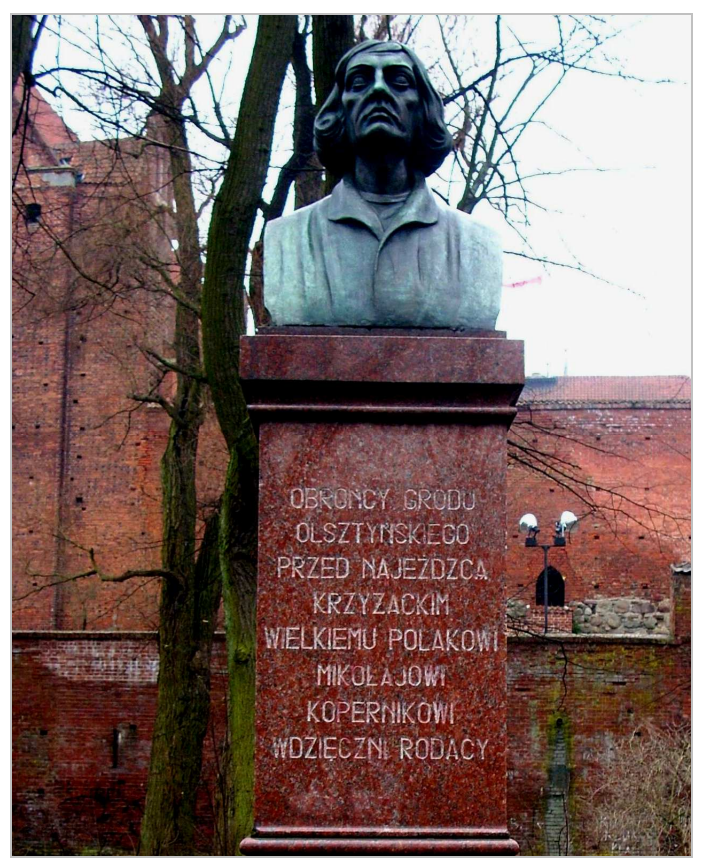

Ryc. 1. Popiersie

Mikołaja Kopernika

z 1916 r. z polskim

powojennym napisem

Źródło: fot. I. Lewandowska 
O spolszczeniu nazw niemieckich - miast, wsi, obiektów fizjograficznych, drogowskazów, a nawet nazwisk - pisał w innym memoriale Mieczysław Rogalski. Obce napisy w miastach były wszechobecne. Prócz tego niemiecka spuścizna widoczna była w: czerwonej cegle; cmentarzach z niemieckimi nagrobkami, które pozostawano bez opieki; pamiątkowych tablicach i pomnikach, które niszczono, a na ich miejsce stawiano nowe, świadczące o związkach z polskością (zob. Lewandowska 2010).

Wrogość osadników i władz wszystkich szczebli wobec niemieckiego dziedzictwa widoczna była na całych Ziemiach Zachodnich i Północnych. Dobitnie zostało to odzwierciedlone w oświadczeniu Przewodniczącego Wojewódzkiej Komisji Planowania Gospodarczego we Wrocławiu w sprawie pałacu Hatzfeldtów: „Polska Ludowa nie będzie odbudowywać pałaców junkierskich”. Popularny był też slogan „zabytki-zbytki” oraz hasła, w których głoszono, że „burżujskie” zamki, pałace, kościoły i kamienice to „przeżytki ideologiczne” (Lubocka-Hoffman 2004, s. 27). Negowano tym samym dobra kultury nie tylko ze względu na ich niemieckie pochodzenie, ale także na to, że należały do bogatych właścicieli ziemskich czy Kościoła, a więc do grup głoszących inną ideologię niż socjalistyczna.

„Odniemczanie” rozumiano jako wysiedlenie ludności niemieckiej, przejęcie jej mienia oraz usunięcie śladów kultury niemieckiej zarówno materialnej, jak i duchowej. Ministerstwo Ziem Odzyskanych wydało w tym celu w czerwcu 1947 r. okólnik, w którym polecało „usunięcie niemieckich napisów z kościołów, kaplic, cmentarzy, krzyży przydrożnych itp. obiektów kultu religijnego". Ponadto należało:

usunąć wszelkie napisy nie tylko na budynkach publicznych, [...] ale również w budynkach prywatnych (bramach i klatkach schodowych), [...] w lokalach gastronomicznych, kawiarniach, sklepach itp., lokalach, gdzie widnieją one zwłaszcza na różnych nieprzedstawiających wartości obrazach (oleodrukach) i różnych drobnych przedmiotach (Rutkowska 2000, s. 175).

W prasie pojawiały się głosy, że ziemie te „uformowane [zostały - przyp. I.L.] przez obcą i wrogą nam niemczyznę, [a ich - przyp. I.L.] układ osiedli, zabudowa i wszelkie pozostałości rzeczy poniemieckich” mogłyby „zniekształcić naszą kulturę" (Kaczorowski 1945, s. 2). Polacy mają obowiązek zachowania czujności, „by przełamać genius loci osiedli niemieckich [...], by nie wkomponować się w elementy krajobrazu kulturowego zafundowanego nam przez niemców" (Kaczorowski 1946, s. 3).

Zbigniew Rewski, konserwator zabytków w województwie olsztyńskim, jeszcze kilka lat po zakończeniu wojny nawoływał do pozbawienia architektury Ziem Zachodnich cech pruskich. Twierdził on, że: 
do zabytków architektury, nawet tych, które nie wiążą się z polskością, winniśmy mieć stosunek pozytywny, po pierwsze dlatego, że posiadają one poważną wartość artystyczną i kulturalną, a po drugie, iż tkwiące w nich obce pierwiastki polityczne zdezaktualizowały się całkowicie i nie stanowią dla naszej państwowości żadnego niebezpieczeństwa. Natomiast zgoła odmienny stosunek mamy [...] do zabudowy pruskiej [...]. Nie mogąc zniszczyć ani usunąć tej zabudowy, choć teoretycznie byłoby to jedynie skuteczne rozwiązanie, winniśmy świadomie dążyć do stopniowego złagodzenia jej najbardziej jaskrawego ostrza (Rewski 1949a, s. 2).

Paradoksalnie Rewski upatrywał sprzyjających warunków w skutkach wojny, tj. w zrujnowanej architekturze, którą stosunkowo łatwo było odbudować, łagodząc jej niemiecki charakter. Wśród cech typowych dla architektury pruskiej drugiej połowy XIX i początku XX w. wymieniał m.in. ceglane mury, które różniły się tym od krzyżackich, że do ich budowy używano fabrycznej cegły prasowanej lub licówki klinkierowej. W średniowieczu cegła była wykonywana ręcznie i nie miała tak „ostrego" charakteru. Drugim elementem był monumentalizm przejawiający się w skoszarowanych gmachach, kolosalnych budynkach i kilometrach murów. Trzecią cechą natomiast, najbardziej trudną do zmienienia, była panorama miast odzyskanych, wyrażająca się w szpicach i hełmach kościołów, ratuszów oraz wież ciśnień. W związku z tym Rewski zaproponował remont elewacji poczty w Olsztynie i usunięcie dwóch szpiców z wieży kościoła garnizonowego (Rewski 1949a).

O zachowanie zabytkowej architektury i historycznego układu przestrzennego miast dbali - w przeciwieństwie do urbanistów i architektów - konserwatorzy zabytków. Zgodnie z zaleceniami wydanymi na IV Międzynarodowym Kongresie Architektury Nowoczesnej w Atenach w 1933 r., by dobro mieszkańców przedkładać nad dobro zabytków, niewątpliwie uszczuplono walory artystyczne, urbanistyczne i architektoniczne odbudowywanych po wojnie zespołów staromiejskich. Architekci dążyli do rozluźnienia zabudowy, by uczynić miasta bardziej przestrzennymi i zdrowszymi. Postulowali, aby „w stare centra miejskie tchnąć nowe życie”, a ,zniszczone dziedzictwo rekonstruować nie historycznie”, lecz „w odniesieniu do nowych zadań i w nowych formach" (Majewski 2009, s. 260). Zniszczenia wojenne pozwoliły im przeforsować u władz własne koncepcje odbudowy. Problem dotyczył głównie kamienic, którym obcięto trzeci trakt, skracając tym samym ich wnętrza i zyskując więcej przestrzeni na zapleczu budynków. W ten sam sposób pozbywano się oficyn, a wolne przestrzenie zagospodarowywano na zieleńce i place zabaw. Działalność architektów źle odbiła się na zabytkowym układzie przestrzennym, bowiem w miastach poszerzano dotychczasowe ulice, tworzono obwodnice starówek i wprowadzano drogi szybkiego ruchu przez same centra. Sprzeciwiali się temu konserwatorzy zabytków, którzy jednak nie mieli w ówczesnych czasach zbyt dużego wpływu na kształtowanie przestrzeni. 


\section{Wlączanie zabytków do życia}

W tej sytuacji konserwatorzy skupili się na ochronie i odbudowie monumentalnych zabytków architektury - kościołów, ratuszy, zamków, fortyfikacji, które były powszechnie akceptowane i zyskiwały przychylność władz. Konserwatorzy nie ograniczali się do tradycyjnego pojęcia „dzieła sztuki-pomnika” i cenili uznane, wielkie dzieła dawnych epok. Jednak należało je tak odbudować, by odgrywały rolę obiektów użytkowych. Było to zgodne z narodowym programem odbudowy, ogłoszonym już w 1945 r. przez Generalnego Konserwatora Zabytków Jana Zachwatowicza. Twierdził on, że „Naród i pomniki jego kultury to jedno” i duży nacisk kładł na „włączenie zabytków do życia” (Zachwatowicz 1946, s. 48-52). Gwarancją przetrwania zabytków powinien być społeczny wymiar ich funkcjonowania. Każdy zabytek „musi znaleźć dla siebie treść życiową najbardziej odpowiednią, a zapewniającą mu dalszą egzystencję" (Zachwatowicz 1981, s. 36-38).

W myśl tej zasady odbudowano ratusze w Morągu i Ornecie, starówkę w Olsztynie, a w późniejszych latach zamki w Pasłęku, Giżycku, Lidzbarku Warmińskim, Kętrzynie i Reszlu. Na Pasłęk zwrócono uwagę już w 1948 r. Rozpoczęto od robót zabezpieczających przy ratuszu, a następnie przeniesiono się na XIV-wieczny zamek krzyżacki. Pomiary zamku wykonali studenci Politechniki Warszawskiej i odkryli, że:

pokryte niepotrzebnie tynkiem filary w parterze lewego skrzydła wykonane są z kamienia, a całe wnętrze, podzielone później ściankami na małe klitki, stanowiła jednak wielka sala sklepiona, oparta na biegnących środkiem gotyckich filarach (Rewski 1949b, s. 210).

Całość starano się tak odbudować, by odkryć stare średniowieczne założenia, a sale zamku przeznaczyć na pomieszczenia, w których miały mieścić się urzędy i instytucje użyteczności publicznej.

Podobnie ustosunkowano się do Wzgórza Katedralnego we Fromborku. Po opuszczeniu miasta przez Armię Czerwoną ukonstytuował się komitet lokalny z burmistrzem na czele, który zainicjował akcję uporządkowania zespołu katedralnego i opieki nad nim. W 1946 r. cały zespół, oprócz kościoła, przeszedł na własność państwa, co umożliwiło jego finansowanie przez Ministerstwo Kultury i Sztuki. Początkowo uzupełniono ubytki w dachu i oszkleniu okien, a w 1948 r. zdecydowano przeznaczyć ten obiekt na Muzeum Mikołaja Kopernika. Koncepcja odbudowy zakładała przywrócenie charakteru budynku, odpowiadającego epoce kopernikowskiej. Prace rozpoczęto od zburzenia gmachu dawnej biblioteki biskupiej, tzw. wikarówki i kanonii. W ten sposób odkryto stare zabytkowe budowle, zrekonstruowano gotycką wieżę i gmach muzealny z cennym portalem wczesno- 
gotyckim (Pietrzak-Pawłowska 1948). W trakcie robót konserwatorskich odkryto nieznane przed wojną autentyczne późnogotyckie stropy drewniane w budynku Muzeum Mikołaja Kopernika oraz strzelnice w Wieży Kopernika, gdzie znaleziono również gotycką polichromię (Brwiliński 1953). Wyburzono też neogotyckie dobudówki niemieckie, zmieniające wygląd wnętrz zamku, oraz uporządkowano mury obronne i cały teren dziedzińca zamkowego. Wymagało to specjalnych badań i studiów archeologiczno-konserwatorskich.

Nakładanie się różnych warstw architektoniczno-użytkowych widać w zmianach zamku olsztyńskiego. Zbudowany przez kapitułę warmińską w drugiej połowie XIV w., po rozbiorach Polski ulegał zmianom spowodowanym przeznaczeniem do pełnienia funkcji administracyjnych. Do znacznych zmian w wyglądzie zamkowych wnętrz doszło na początku XX w., gdy część pomieszczeń zaadaptowano na cele mieszkalne i sale reprezentacyjne dla urzędującego w zamku prezydenta rejencji olsztyńskiej. Podwyższono wówczas wszystkie wnętrza w skrzydle północnym poprzez obniżenie poziomu podłóg o ok. 1,2 m. Skutkiem tego była konieczność rozebrania gotyckich sklepień w przyziemiu (Rzempołuch 2004). Po drugiej wojnie światowej, w 1948 r., w wyniku omówionej powyżej koncepcji konserwatorskiej dokonano poważnego remontu sal gotyckich, którym przywrócono poprzedni wygląd. Z sal rycerskich pozbyto się boazerii drewnianej, niezgodnej ze stylem epoki, oraz odsłonięto sklepienia zakryte płaskimi stropami żelbetowymi. Przy okazji usunięto także kominek z początku XX w. i pruskie orły ${ }^{2}$.

Znalezienie użytkowników w przypadku tak wielkich budowli było niezwykle trudne. Nowy użytkownik, zgodnie z własnymi koncepcjami wykorzystania budynku, przeprowadzał remonty i dostosowywał zabytek do bieżących potrzeb. Twierdzę Boyen oraz zamek w Giżycku przejęło wojsko. Ten ostatni, zbudowany w stylu gotyckim, ale gruntownie przebudowany w 1614 r., posiadał widoczne cechy baroku. Nieliczne neogotyckie elementy były łatwe do usunięcia. O zamku i otaczającym go założeniu parkowym konserwator Zbigniew Rewski w 1949 r. pisał:

Rozległość terenu parku daje architektowi możliwość rozwiązania sytuacji nowego gmachu w ten sposób, by nie ucierpiało na tym piękno zabytkowej architektury. Przy tej okazji będzie można oczyścić zamek z nowszych poniemieckich dobudówek, których spalone mury szpecą zamek (Rewski 1949c, s. 210).

Niestety inne monumentalne zabytki musiały czekać na nowego użytkownika przez wiele lat. Jeszcze w 1953 r. zamek biskupów warmińskich w Lidzbarku

${ }^{2}$ Archiwum Państwowe w Olsztynie, zespół Muzeum Mazurskie (APO/MM), Sprawozdania, statystyka 1945-1953, sygn. 501/II/13, k. 85. 
o kubaturze kilkudziesięciu tysięcy metrów sześciennych stał pusty i - podobnie jak zamek w Reszlu czy wieża w Przezmarku - był strzeżony przez dozorców zatrudnionych przez Ministerstwo Kultury i Sztuki.

\section{Odbudowa architektury Olsztyna}

Przy odbudowie Starego Miasta w Olsztynie ścierały się rozmaite koncepcje urbanistyczne, z czego dwie uznano za najważniejsze. W jednej zakładano wierną rekonstrukcję przedwojennej zabudowy, w drugiej stawiano na budownictwo współczesne. Ostatecznie przyjęto założenie wyeliminowania istniejących uprzednio fasad z XIX w., które identyfikowano z duchem niemieckim. Ulice Staromiejską i Prostą odtworzono na poprzedniej siatce urbanistycznej, ale według nowych pomysłów architektonicznych i zdobniczych. Podobnie było z kamienicami zlokalizowanymi przy Rynku Staromiejskim. Tu zdecydowano się zastosować rekonstrukcję stylizowaną na barok. Z jednej strony ten okres dziejów Warmii najbardziej kojarzył się z kulturą polską, z drugiej zaś brakowało źródeł ikonograficznych, kartograficznych i historycznych, na których mogłyby się oprzeć działania konserwatorskie. W związku z tym fasady domów odtwarzano przez analogię do podobnych zachowanych kamienic. Mimo że w barokowych elewacjach kamieniczek mieszczańskich, które przetrwały do czasów powojennych, częstszą była trójkątna, wysmukła forma szczytu, to w Olsztynie zdecydowano się na ich bogate, esowate kontury znane $\mathrm{z}$ reprodukcji kamieniczek lidzbarskiego rynku (Vetulani 1958). Być może wynikało to także z propagandowego hasła, głoszonego przy odbudowie miast na Ziemiach Zachodnich i Północnych, np. Gdańska: „Odbudujemy Gdańsk piękniejszy niż był”. Domy lokowano na historycznych parcelach, ale skracano do dwóch traktów i podwyższano o jedną kondygnację w stosunku do stanu budynku z okresu, na którym się wzorowano. Miało to $\mathrm{z}$ jednej strony charakter ekonomiczny, $\mathrm{z}$ drugiej zaś podnosiło prestiż miasta (Knercer 2002).

Poza obszarem staromiejskim częstokroć elewacje budynków wzniesionych w XIX i XX w., a nawet starszych, odzierano z bogatej dekoracji sztukatorskiej i kładziono $w$ ich miejsce gładkie tynki niszczące ich zabytkowy charakter (podobnie było w Ornecie). W bocznych ulicach pozbywano się wieżyczek o dzwonowatej konstrukcji, zwieńczonych gałką, na której osadzono krótką iglicę. Przypominały one pikielhauby - nakrycia głowy oficerów pruskiej armii. Przykładami są: budynek w narożniku Rynku Starego Miasta i ulicy Prostej (ryc. 2, 3), pierwsza od strony wiaduktu kolejowego kamienica przy ulicy Marii Curie-Skłodowskiej, 
kamienice przy dzisiejszej ulicy Adama Mickiewicza oraz wieżyczka na dachu restauracji „Nowe Jakubowo" w Lesie Miejskim (Bętkowski 2003). Innym exemplum jest pałacyk przy ulicy Metalowej 6, w którym mieści się obecnie Muzeum Przyrody. Przed wojną budynek ten w północnym narożniku miał pięcioboczną wieżyczkę przykrytą kopulastym hełmem, zamienionym po wojnie na płaski dach (Piechocki 2002).

Starano się ponadto zatuszować monumentalizm budowli, zmieniając ich kształty, o czym świadczy m.in. dawny gmach starostwa (dziś budynek UWM) przy ulicy Szrajbera. Innym sposobem było obsadzenie obiektu architektonicznego drzewami, których zieleń zakrywała czerwoną licowaną cegłę, np. przy dawnym gmachu rejencji, znajdującym się przy dzisiejszej alei Józefa Piłsudskiego. Ostatecznie decydowano się podczas odbudowy czy remontu na usunięcie cech architektury pruskiej, jak chociażby szczytów ze sterczynami. Tak się stało w przypadku budynku przedwojennego gimnazjum klasycznego, obecnie I Liceum Ogólnokształcącego przy ulicy Mickiewicza.

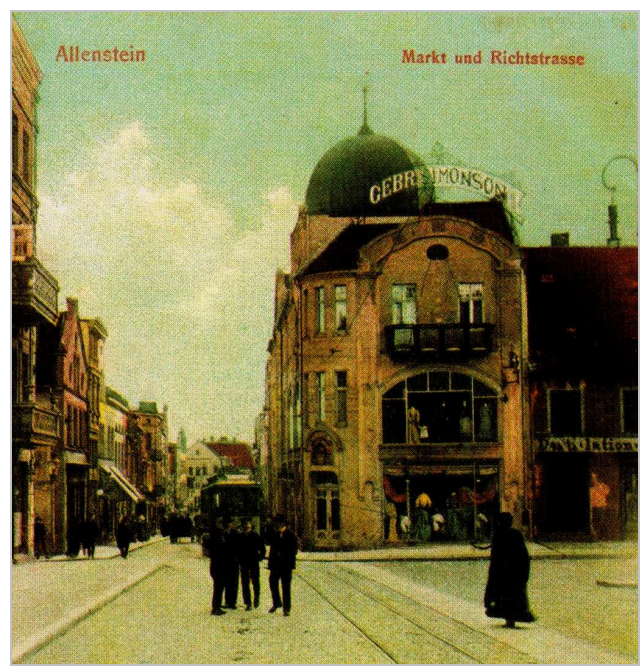

Ryc. 2. Narożnik rynku i ulicy Prostej w Olsztynie $1908 \mathrm{r}$. Źródło: R. Bętkowski (2003, s. 44)

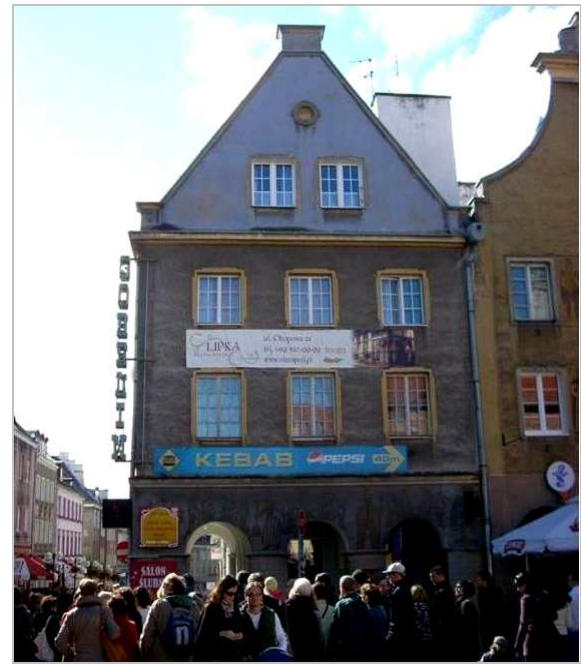

Ryc. 3. Narożnik rynku i ulicy Prostej w Olsztynie współcześnie Źródło: fot. I. Lewandowska

Ciekawym przykładem palimpsestu są pomniki. Dzisiaj najpopularniejszym i najbardziej kontrowersyjnym obiektem zabytkowym w Olsztynie jest pomnik Wdzięczności Armii Czerwonej (obecna nazwa: pomnik Wyzwolenia Ziemi Warmińsko-Mazurskiej) autorstwa Xawerego Dunikowskiego, postawiony w 1954 r. 
przy głównej arterii miasta (niegdyś aleja Zwycięstwa, dzisiaj - Józefa Piłsudskiego). Monument powstał z granitowych głazów z mauzoleum gen. Paula Hindenburga pod Olsztynkiem. Ten pomnik zwycięstwa armii niemieckiej w $1914 \mathrm{r}$. pod Tannenbergiem, wzniesiony w 1927 r., a w 1935 r. przekształcony w mauzoleum Hindenburga, został wysadzony w powietrze przez wycofujący się Wehrmacht w styczniu 1945 r. Przez lata stał w ruinie. Ostatecznie, z inicjatywy ówczesnego wojewody olsztyńskiego Mieczysława Moczara, jego elementy zostały przetransportowane do Olsztyna i użyte do budowy pomnika - hołdu żołnierzom radzieckim, zwycięzcom - okupantom Warmii i Mazur. Inne trafiły do Warszawy, gdzie zostały wykorzystane jako posadzka przed gmachem KC PZPR (Tomkiewicz 1998).

\section{Oswajanie zabytków kościelnych}

Oswajanie architektury dotyczyło także zabytków kościelnych. Kościoły katolickie przeważnie odbudowywano i przeznaczano na cele sakralne i tylko niewielką ich część adaptowano do innych funkcji. Dla przykładu we Fromborku w kościele pw. św. Mikołaja funkcjonowała kotłownia miejska, a w zespole Szpitala św. Ducha urządzono Muzeum Medycyny.

Władze wymagały zacierania napisów niemieckich na witrażach i ścianach kościołów, ale nie były w stanie wymusić tego na całym duchowieństwie katolickim. Niektóre z napisów zachowały się do dziś, świadcząc o wielokulturowej tradycji tych ziem. W Archiwum Parafialnym Sanktuarium Znalezienia Krzyża Świętego w Klebarku Wielkim zachowało się pismo komendanta Milicji Obywatelskiej w Klebarku do proboszcza z 21 lipca 1946 r. Autor dokumentu nakazuje:

natychmiastowe usunięcie z przed ołtarzy i całego Kościoła Rz.Katol. wszystkich napisów w języku niemieckiem. $\mathrm{O}$ ile te napisy nie zostaną natychmiast usunięte to jestem zmuszony Księdza Proboszcza przedstawić w doniesieniu do obywatela Starosty Pow. z prośbą o karanie Księdza Proboszcza Karą Administracyjną ${ }^{3}$.

Aby wykonać to polecenie, a jednocześnie całkowicie nie zniszczyć witraży z niemieckimi napisami, ówczesny proboszcz polecił zasmołować te fragmenty, by nie rzucały się w oczy. Na szczęście witraży nie wybito i można je było z czasem całkowicie oczyścić i zakonserwować. Nakładanie się różnych warstw językowych widać w podpisach do drogi krzyżowej w kościele pw. św. Jana Chrzciciela w Giławach w powiecie olsztyńskim. Po drugiej wojnie światowej niemieckie

${ }^{3}$ Archiwum Parafialne Sanktuarium Znalezienia Krzyża Świętego w Klebarku Wielkim, dokument z 1946 r. 
oryginalne podpisy z początku XX w. zastąpiono tekstem polskim. Dzisiaj, przy odpowiednim oświetleniu obrazów drogi krzyżowej, widoczne są obydwie warstwy (Lewandowska 2002).

Najwięcej zabiegów czyniono przy oswajaniu kościołów ewangelickich. W myśl Ustawy z dnia 6 maja 1945 r. o majątkach opuszczonych i porzuconych budynki te uznano za mienie poniemieckie. Kilka miesięcy później Ministerstwo Administracji Publicznej stwierdziło, że:

świątynie [ewangelickie] znajdują się pod opieką władz państwowych, a ich przeznaczenie zostanie określone $\mathrm{w}$ przyszłości $\mathrm{w}$ drodze ustawowej [...]. Dysponowanie tymi obiektami należy do Tymczasowego Zarządu Państwowego. Przekazanie w użytkowanie może nastąpić po uprzednim uzyskaniu zgody Ministerstwa Administracji Publicznej (Lubocka-Hoffman 2004, s. 79).

Wiele kościołów przez lata stało pustych i ulegało stopniowej ruinie, inne ogołacano ze stałych elementów wyposażenia, typowych dla wyznania ewangelickiego. Drażliwym i trudnym do zaakceptowania przez katolików elementem wyposażenia świątyń były empory, loże kolatorskie, ołtarze kazalne (ambonowe), tablice psalmów oraz wiszące figury anioła chrzcielnego (ryc. 4). Często były one demontowane i niszczały w składzikach lub na strychach. Podobnie było z XVI-

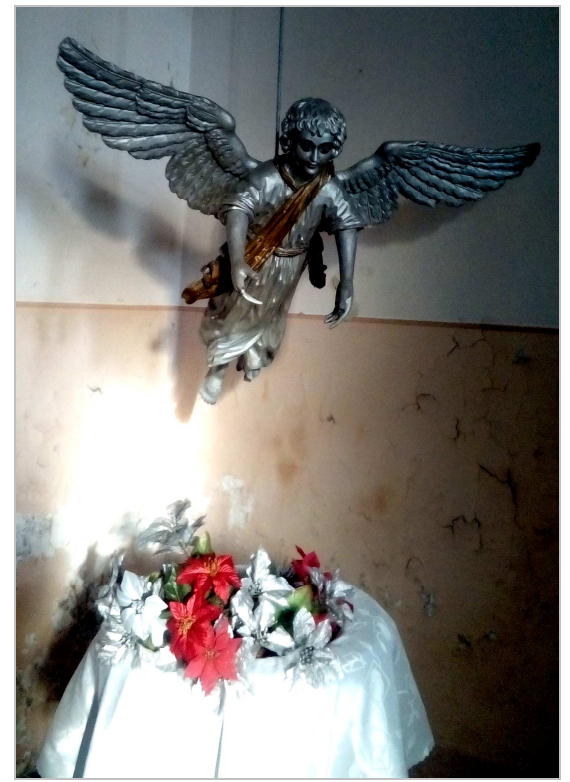

Ryc. 4. Anioł chrzcielny w kościele w Gierzwałdzie, gm. Grunwald Źródło: fot. I. Lewandowska -wiecznymi płytami epitafijnymi, które ludność utożsamiała z kulturą niemiecką, nie doceniając ich historycznego znaczenia. Zdarzało się także, że wycinano epitafium z pięknie rzeźbionej ramy, w którą wstawiano obraz religijny bliski osadnikom i otaczany szczególną czcią, często przywieziony na nowe ziemie z dalekich Kresów Wschodnich (np. Matka Boska Ostrobramska lub Matka Boska Częstochowska) (Liżewska 2002).

Innym problemem było przejmowanie świątyń ewangelickich przez katolików. Czasami ludność czyniła to spontanicznie, gdyż proporcje wyznaniowe na Warmii i Mazurach po drugiej wojnie światowej odwróciły się. Katolicy tłumaczyli, że jest ich znacznie więcej niż ewangelików i dlatego 
to im należy się kościół, tym bardziej że większość z nich przed reformacją należała do Kościoła katolickiego. Na przykład mieszkańcy gminy Wesołowo w powiecie morąskim uzasadniali zajęcie przez siebie świątyni ewangelickiej tym, że w gminie mieszkało 850 katolików i tylko 137 ewangelików, natomiast najbliższy kościół katolicki był oddalony od wsi o $12 \mathrm{~km}$. Jako argument podawano także, że Kościół ewangelicko-augsburski przez kilka lat po wojnie nie opanował trudności organizacyjnych:

wielka ilość kościołów (31) i kaplic (19) tego wyznania stoi niewykorzystana z powodu braku wyznawców lub niedostatecznego zainteresowania. [...] Główną przyczynę stanowi rozpaczliwy brak pastorów, 11 pastorów ma do obsłużenia 87 obiektów kościelnych (Michalak 2002, s. 216, 220).

\section{Zagospodarowywanie poniemieckich palaców i dworów}

Negatywny był również stosunek do poniemieckich pałaców i dworów, tak licznie rozsianych na terenach dawnych Prus Wschodnich. Zajęcie tych zabytków przez Państwowe Gospodarstwa Rolne stopniowo doprowadziło zarówno same pałace, jak i przypałacowe parki i ogrody do ruiny. Powszechna negacja użytkowania pojunkierskich dworów i pałaców przez PGR-y nie jest problemem łatwym do oceny. Znamy bowiem przypadki wybierania na zarządców w pierwszych latach powojennych dawnych właścicieli lub zarządców, którzy najlepiej znali potrzeby ochrony pałacu i parku. PGR-y posiadały ponadto fundusze remontowe, które przeznaczały na remonty i doraźne zabezpieczenia obiektów. Gorsza była sytuacja tych pałaców, w których urządzano kolonie letnie lub wczasy pracownicze. Użytkowane tylko w sezonie letnim, a przy tym niszczone przez użytkowników, nieremontowane i niezabezpieczane przez pozostałe miesiące $\mathrm{w}$ roku, szybko kończyły swój żywot. W jeszcze gorszej sytuacji pozostawały te zabytki, które nie były użytkowane w ogóle. Nieogrzewane, narażone na dewastację, niestrzeżone przed szabrownikami lub chuliganami, popadały w ruinę i często nie można ich już było uratować.

W pierwszych latach powojennych stan pałaców, dworów i ogrodów był jeszcze na tyle dobry, że w przypadku poważnego finansowania mogły zostać odnowione i uratowane. Niestety łożenie ogromnych sum pieniędzy na restaurację tych zabytków nie było wówczas możliwe. Wynikało to nie tylko z trudności finansowych państwa, ale przede wszystkim z negacji samego społeczeństwa. Jeden z osadników wspominał, jak ówcześni mieszkańcy odnosili się do parku okalającego dwór w Piastach Wielkich: 
Drewniane, niewielkie budowle dorośli, nie bacząc na ich piękno, rozbierali, wykorzystując uzyskane deski i okienka na budowę swych kurników i klatek dla królików. Ściągano też dachy z murowanych ,świątyń dumania” dawnych pań i panów. Robiono to za dnia, zupełnie legalnie, gdyż kierownictwu majątku [państwowego majątku ziemskiego - przyp. I.L.] nie był potrzebny ani park, ani wszystko, co się w nim znajdowało (Knercer 2000, s. 277).

Świadczyło to nie tylko o negatywnym stosunku ludności do niemieckiego dziedzictwa kulturowego, ale również do spuścizny wielkopańskiej, niewygodnej i negowanej w nowym, komunistycznym ustroju. Podobnie zresztą do pałaców i dworków szlacheckich odnoszono się na terenach rdzennie polskich. W związku z tym trudno dopatrywać się tu postaw tylko antyniemieckich.

\section{Podsumowanie}

W przytoczonych powyżej przykładach wyraźnie widać dwa tory myślenia i działania ludności polskiej przybyłej na Warmię i Mazury po drugiej wojnie światowej. Przeplata się tu chęć zniszczenia wszystkiego, co niemieckie, z chęcią ratowania wszelkich dóbr kultury, bez względu na ich historyczną genezę.

Warto zwrócić uwagę na to, jaką postawę przyjęly władze konserwatorskie wobec usuwania naleciałości i przebudowań architektonicznych, które zmieniały pierwotny wygląd zabytkowego obiektu. W wyniku wielomilionowych nakładów finansowych możliwa była regotyzacja kilku obiektów, m.in. zamków w Kętrzynie, Nidzicy czy Olsztynie oraz Wzgórza Katedralnego we Fromborku. Powrót do pierwotnej architektury nie zawsze był już możliwy, trzeba bowiem pamiętać, że władze pruskie także niezbyt łaskawie obchodziły się z zabytkami. Dla przykładu kamienice $\mathrm{z}$ charakterystycznymi podcieniami w Kętrzynie, które znajdowały się w południowej pierzei rynku, rozebrano w połowie XIX w. W latach 1780-1783 zburzono też gotycki ratusz, a na jego miejscu stanął parterowy budynek, w którym umieszczono posterunek policji, a następnie sklep z meblami (Korowaj 2005). Takich egzemplifikacji jest więcej.

Po drugiej wojnie światowej muzealnicy, konserwatorzy zabytków, pracownicy nauki, bibliotekarze - ludzie wykształceni i doceniający bogactwo kulturowe tych ziem - musieli stawiać czoła osobom zamierzającym wyrugować niemiecką spuściznę. W tej grupie znajdowali się m.in. funkcjonariusze partyjni, często karierowicze, którzy za wszelką cenę chcieli pokazać władzom zwierzchnim swoją działalność w terenie. Byli też zwykli, prości ludzie, niemający świadomości różnorodnego dziedzictwa Ziem Północnych i Zachodnich. Dla nich oswojenie nieprzyjaznego krajobrazu, np. wyglądu czy wystroju budynków, świątyń, pomni- 
ków, napisów, cmentarzy itp., było sprawą najważniejszą, by móc żyć w nowym otoczeniu bezpiecznie i by potrafić je zaakceptować.

Analiza motywów postępowania ówczesnych mieszkańców Warmii i Mazur jest równie trudna jak badanie świadomości ludzkiej z perspektywy kilkudziesięciu lat $\mathrm{i}$ funkcjonowania $\mathrm{w}$ innym ustroju państwowym. Nowe palimpsesty wciąż czekają na odkrycie i poddanie ich dogłębnej analizie.

\section{Literatura}

Bętkowski R., 2003, Olsztyn, jakiego nie znacie. Obraz miasta na dawnej pocztówce, Olsztyn.

Brwiliński Z., 1953, Prace konserwatorskie. Województwo olsztyńskie, „Ochrona Zabytków", 6/1 (20), s. 64-67.

Domagała T., 1998, Miasta wschodniopruskie w okresie zimowej ofensywy Armii Czerwonej w 1945 roku, [w:] Lubocka-Hoffmann M. (red.), Odbudowa miast historycznych, Elbląg, s. 40-54.

Filipkowski T., 1980, Zagadnienia Prus Wschodnich $w$ memoriałach przedtożonych Polskiemu Komitetowi Wyzwolenia Narodowego, „Komunikaty Mazursko-Warmińskie”, 1, s. 53-79.

Jasiński J., 2002, Zmiany w krajobrazie wsi warmińskiej w XIX wieku, [w:] Achremczyk S. (red.), Życie codzienne na dawnych ziemiach pruskich. Świadectwa przeszłości, Olsztyn, s. 157-171.

Jasiński J., 2006, Kwestia pojęcia Ziemie Odzyskane, [w:] Sakson A. (red.), Ziemie Odzyskane - Ziemie Zachodnie i Pólnocne 1945-2005: 60 lat w granicach państwa polskiego, Poznań, s. 27-44.

Kaczorowski M., 1945, U progu prac nad odbudowa, „Skarpa Warszawska”, 1, s. 2.

Kaczorowski M., 1946, Dlaczego Warszawa, „Skarpa Warszawska”, 27-28, s. 3.

Knercer W., 2000, Losy zatożeń palacowo-parkowych i dworsko-parkowych na terenie województwa olsztyńskiego, [w:] Mazur Z. (red.), Wspólne dziedzictwo? Ze studiów nad stosunkiem do spuścizny kulturowej na Ziemiach Zachodnich i Pótnocnych, Poznań, s. 267-285.

Knercer W., 2002, Stosunek państwa i społeczeństwa polskiego do spuścizny kulturowej Warmii i Mazur w pierwszych latach po II wojnie światowej w świetle ówczesnej prasy, „Studia Angerburgica”, 7, s. 122-126.

Korowaj T., 2005, Rastenburg/Kętrzyn. Przewodnik historyczny po mieście, Kętrzyn.

Lewandowska I., 2010, Oswajanie poniemieckiej przestrzeni nazewniczej na Warmii i Mazurach po II wojnie światowej, [w:] Nowosielska-Sobel J., Strauchold G., Kucharski W. (red.), Nazwa dokumentem przeszlości regionu, Wrocław, s. 35-64.

Lewandowska I., 2012, Trudne dziedzictwo ziemi. Warmia i Mazury 1945-1989, Olsztyn. 
Liżewska I., 2000, Zabytki w naszych rękach. O ochronie dóbr kultury na Warmii i Mazurach w latach 1945-1989, [w:] Mazur Z. (red.), Wspólne dziedzictwo? Ze studiów nad stosunkiem do spuścizny kulturowej na Ziemiach Zachodnich i Pólnocnych, Poznań, s. 239-265.

Liżewska I., 2002, Oswajanie przestrzeni. O poewangelickich wnętrzach na Warmii i Mazurach, „Borussia”, 26, s. 225-232.

Lubocka-Hoffman M., 2004, Miasta historyczne zachodniej i pótnocnej Polski. Zniszczenia i programy odbudowy, Elbląg-Bydgoszcz.

Łukowski W., 2002, Spoleczne tworzenie ojczyzn. Studium tożsamości mieszkańców Mazur, Warszawa.

Majewski P., 2009, Ideologia i konserwacja. Architektura zabytkowa w Polsce w czasach stalinizmu, Warszawa.

Michalak R., 2002, Problem przejmowania kościołów ewangelickich przez Kościól rzymskokatolicki na Mazurach po drugiej wojnie światowej, „Borussia”, nr 26, s. 211-224.

Muszyński J., 1997, Z doświadczeń w stużbie konserwatorskiej, [w:] Mazur Z. (red.), Wokót niemieckiego dziedzictwa kulturowego na Ziemiach Zachodnich i Pólnocnych, Poznań, s. 231-256.

Pawłowska K., 1996, Idea swojskości w urbanistyce i architekturze miejskiej, Kraków.

Piechocki S., 2002, Olsztyn magiczny, Olsztyn.

Pietrzak-Pawłowska I., 1948, Otwarcie Muzeum Mikołaja Kopernika we Fromborku, „Przegląd Zachodni”, 11, s. 553-555.

Rewski Z., 1949a, O odprusaczenie architektury ziem zachodnich, „Odra”, 7, 16 III, s. 2.

Rewski Z., 1949b, Odkrycia w zamku pasłęckim, „Ochrona Zabytków”, 3, s. 210.

Rewski Z., 1949c, Wojsko polskie zabezpieczyło przed zniszczeniem zamek w Gizycku, „Ochrona Zabytków”, 3, s. 210-211.

Rutkowska M., 2000, Elementy polityki wobec niemieckiej spuścizny kulturowej na Ziemiach Zachodnich (1945-1950), [w:] Mazur Z. (red.), Wspólne dziedzictwo? Ze studiów nad stosunkiem do spuścizny kulturowej na Ziemiach Zachodnich i Pólnocnych, Poznań, s. 167-200.

Rzempołuch A., 2004, Architektura i urbanistyka Olsztyna 1353-1953. Od założenia miasta po odbudowę ze zniszczeń wojennych, Olsztyn.

Tomkiewicz R., 1998, Kulisy powstania Pomnika Wdzięczności dla Armii Radzieckiej, „Komunikaty Mazursko-Warmińskie”, 3, s. 395-416.

Ustawa z dnia 6 maja 1945 roku o majatkach opuszczonych i porzuconych, DzU 1945, nr 17, poz. 97.

Vetulani C., 1958, Konserwacja zabytków w województwie olsztyńskim (I 1953-30 XI 1955), „Komunikaty Mazursko-Warmińskie”, 3, s. 288-301.

Zachwatowicz J., 1946, Program i zasady konserwacji zabytków, „Biuletyn Historii Sztuki i Kultury", 1/2, s. 48-52.

Zachwatowicz J., 1981, Wybór prac, Warszawa. 


\section{Źródła}

Archiwum Państwowe w Olsztynie, zespół Muzeum Mazurskie (APO/MM), Sprawozdania, statystyka 1945-1953, sygn. 501/II/13, k. 85.

Archiwum Parafialne Sanktuarium Znalezienia Krzyża Świętego w Klebarku Wielkim, dokument z 1946 r.

\section{Warmia and Masuria as a palimpsest Adapting post-German land to Polish needs after the Second World War}

Summary

Palimpsest might be used for naming both the land (Warmia and Masuria) and the time period (after the Second World War). It was then that the land was once again "redesigned" with new symbols, names, new architecture with no sign of previous Prussian details and new traditions, connected strongly only to Polish history. After the Germans fled or were deported, new habitants of the region were trying to adapt places of the alien culture to their needs: evangelic churches were transformed into catholic ones, German monuments were destroyed, road signs in German were replaced with ones in Polish, Warmia and Masuria natives were harassed for speaking German language. This article is about destructions of war, government issued orders to de-Germanize the land, quarrels over city designs, adapting monuments to social needs and making use of German palaces and castles.

Keywords: Warmia, Masuria, architecture, social space, landscape changes.

Dr hab. Izabela Lewandowska, prof. UWM

Uniwersytet Warmińsko-Mazurski w Olsztynie

Wydział Humanistyczny

Instytut Historii i Stosunków Międzynarodowych

10-725 Olsztyn, ul. Kurta Obitza 1

e-mail: iza.lewandowska@uwm.edu.pl 